Against method?

\section{Janet Sayers}

\begin{abstract}
A Most Dangerous Method: The Story of Jung, Freud and Sabina Spielrein. By John Kerr. Sinclair-Stevenson/Knopf: 1994. Pp. 607. £25.
\end{abstract}

THIS is not a love story, John Kerr warns. Instead he portrays the romance (1907 - 1913) between Freud, Jung and Sabina Spielrein as a passionately engaging but ultimately "gruesome ghost story" of science betrayed.

Kerr, a clinical psychologist, sets the stage with an account of nineteenthcentury scientific materialism. In Zurich, Jung's word-association experiments were promising to substantiate the otherwise immaterial 'complexes' underlying mental illness, with many of his patients, including Spielrein, showing delayed reaction times to particular stimulus words. Meanwhile Freud, in Vienna, was bothered by his patients' transference onto him of their erotic wishes and desires. He was also trying to re-explain sexual repression; his break with his former colleague Fliess had stopped him attributing it to bisexuality. It was hoped that Freud would soon write a handbook so others could use his method independently, allowing them reliably to interpret and test their patients' free associations in terms of his theories without risk of contamination by suggestion.

But no such manual appeared. Instead, psychoanalytic attention switched from science to symbolism. Freud turned to analysing Jensen's novel Gradiva, the symbols in Leonardo's paintings and the myth of Oedipus, in an attempt to discover the key to the single 'core' sexual complex causing neurosis.

No harm in symbols. They have often been used to advance science. (Kekulé's benzene ring, for example, emerged from his dream of snakes biting each other's tails.) True, as Spielrein pointed out on becoming a medical researcher herself, in madness symbols can become ossifying impersonal idées fixes. For her, however, the symbol of Wagner's Siegfried (misinterpreted by Jung, she said, as her wish to bear his son) served to transform her otherwise backward-looking symptoms (including an obsession with thinking about faeces as she ate, and about her father spanking her brother) into an ideal that she could project herself into in the future.

As for Freud and Jung, their prospects of scientific collaboration ended, Kerr argues, not as others have claimed from the revelation of Jung's sexual liaison with Spielrein (their "poetry" as she put it), but from her scientific papers to the Vienna Psychoanalytic Society. These papers indicated Jung's rejection of Freud's sexual theory of neurosis. She herself went on to develop the hypothesis that sexual repression is due to the threat of selfannihilation involved in immersing oneself sexually in someone else.

Her mentors, however, turned to explaining mental illness in terms of a mythic past. Jung had previously regarded mythic symbols as a means of helpfully recasting and thereby better understanding the incestuous regressions triggered in patients by adolescent conflict. Now he regarded symbols as the cause of both health and disease. He himself nearly succumbed. He become so immersed in an image of a

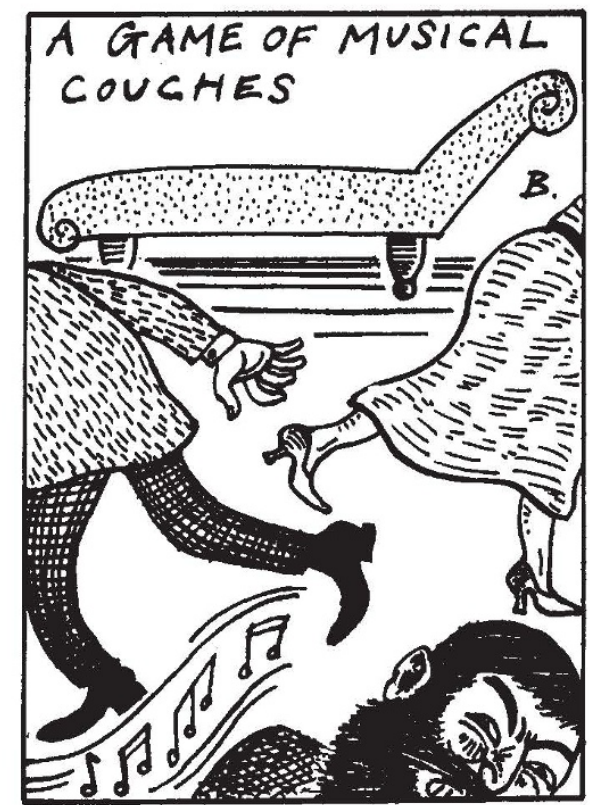

gorgon mother trapping her hero son in the underworld that he could barely surface to complete an article on symbols and their tranformative effects.

Freud too plunged into prehistory. Neurosis, he now insisted, stems from the killing of the father by the primal horde that this is the source of the Oedipus complex. No need, therefore, to look any further for proof of the complex's universality or for validation of its repression as the cause of a patient's symptoms. Nor any need, accordingly, for a primer on psychoanalytic method.

So all hope of psychoanalysis as science died, Kerr claims, apart from a brief flickering with Jung's theory of psychological types - of the extrovert as prone to the transference of neurosis and of the introvert as prey to the inward-looking preoccupations of psychosis. At least these character traits could, and indeed have been, empirically tested.

Kerr's tale finishes, however, with Freud misrecording Spielrein's theory of sexual repression as a precursor of his theory of the death instinct; with Spielrein herself abandoning psychoanalysis first for musical composition and then for work with the psychologists Piaget, Vygotsky and Luria; and with Jung using her as muse for his theory of the anima, which, at the end of his life, he carved into a stone triptych.

As for psychoanalysis, devoid of a clearly stated method for investigating and testing its theories, it became at best a matter of creative guesswork, at worst a matter of indoctrination. No wonder, therefore, that its organizations and journals, which Freud and Jung had done so much to found, quickly deteriorated from platforms for the free exchange of scientific ideas into quasi-religious institutions devoted not to discovering the truth but to propagating and perpetuating dogma, not least through insinuating tittle-tattle against any who dared to dissent.

It is a sorry tale. But to the bitter end Kerr keeps us enthralled with his exhilaratingly informative, sympathetic and thought-provoking account of the real insights and genius that went into the original making of psychoanalysis. $\mathrm{He}$ thereby admirably reverses, and in the process explains, the recent trend towards recounting its history not as science but as gossip.

Janet Sayers is in Keynes College, University of Kent, Canterbury, Kent CTZ 7NP, UK.

\section{Processes and origins}

\section{J. R. L. Allen}

Geomorphology of Desert Environments. Edited by Athol D. Abrahams and Anthony J. Parsons. Chapman and Hall: 1994. Pp. 674. £85, \$16.95.

DESERT environments can support only a limited range and density of specialized organisms, but they unquestionably present a wide and rich variety of geomorphological challenges, if the thickness, weight and length of this book are any criteria.

Geomorphology of Desert Environments contains 26 review chapters prepared by 22 international experts and other active workers from the United States (13), the United Kingdom (5) and Australia, Canada, Germany and New Zealand (1 each). The grouping of chapters into eight sections helps to give a comprehensive account of the geomorphology of deserts - that is, areas of sub-humid to hyper-arid climate - with special emphasis on operative processes.

Part one (two introductory chapters) deals with desert environments generally and presents a geomorphic comparison of the main desert regions. Weathering in deserts is covered in part two (four chapters) dealing with weathering processes and forms, aridic soils, patterned ground and desert pavements, duricrusts and rock 